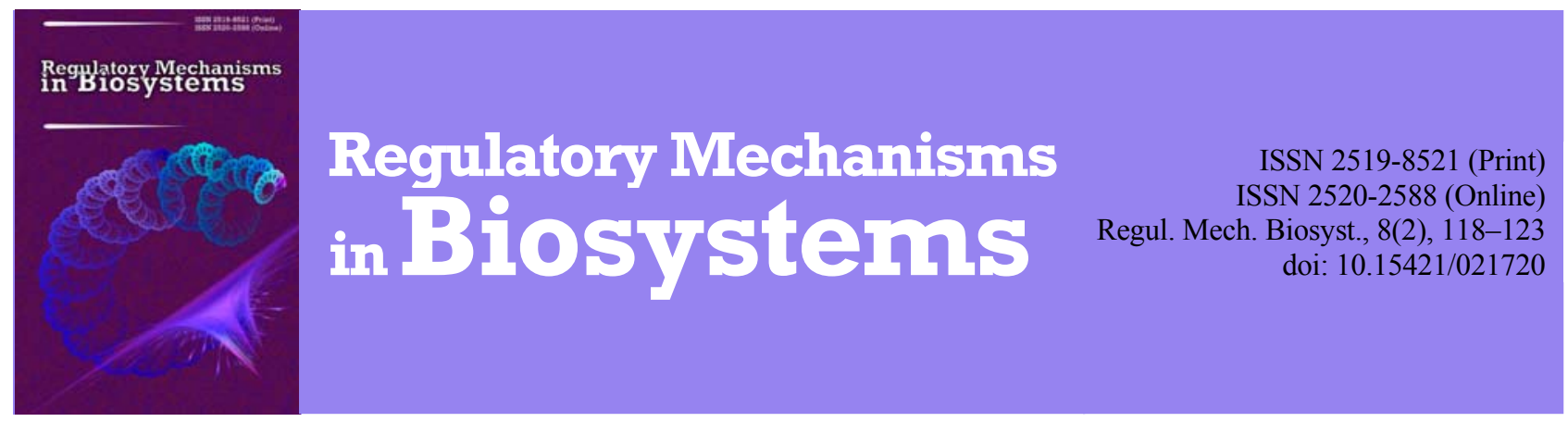

\title{
Structural changes in skeletal muscles in hypokinesia and physical loading in the posthypokinetic period of recovery of rats' organisms
}

\author{
S. L. Popel' \\ Precarpathian V. Stefanyk National University, Ivano-Frankivsk, Ukraine
}

Article info

Received 25.02.2017

Received in revised form 20.03.2017

Accepted 23.03.2017

Precarpathian V. Stefanyk National University, Shevchenko str., 57 ,

Ivano-Frankivsk, 76000, Ukraine Tel.: +38-097-87-41-446.

E-mail:popelsergij@gmail.com
Popel', S. L. (2017). Structural changes in skeletal muscles in hypokinesia and physical loading in the posthypokinetic period of recovery of rats' organisms. Regulatory Mechanisms in Biosystems, 8(2), $118-123$. doi:10.15421/021720

This article reports the study of histo-ultrastructural changes of different structural components of the direct muscle of the thigh of sexually mature male rats over a prolonged period of hypokinesia and subsequent application of the physical loading of average aerobic power. Using a light optical, electronic microscope (for the exposure of structural transformations of muscle components) and histochemical (for determination of activity of succinate dehydrogenase according to the Nahlas method to identify muscle fibers with different phenotypes) methods, we studied the structural manifestations of adaptation of muscle fibres under prolonged (240 day) hypokinesia and 15-30 episodes of physical loading of average aerobic power in the posthypokinetic period among 55 sexually mature rats. Under prolonged hypokinesis we primarily observed changes in the intramuscular network and morphometric changes in the blood vessels. These data closely correlate with the progression of changes of the subcellular components responsible for energetic and flexible balance of muscle fibres. We found that fast oxygen-glycolytic muscle fibers and their peripheral nervous apparatus are the most sensitive to prolonged hypokinesia. As a result of application of the physical loading of average aerobic power, reparative regeneration is intensified, which substantially shortens the period of recovery of structural-functional properties of skeletal muscles in the conditions of hypokinetic disorders. Thus, in prolonged hypokinesia, changes primarily affect the sources of blood supply to skeletal muscles, with the secondary development of reverse processes in muscle fibers and peripheral nervous apparatus with certain morphometric signs.

Keywords: hypokinesia; muscle fibers; blood vessels; physical loading

\section{Структурні зміни в скелетних м'язах за гіпокінезії та фізичного навантаження у постгіпокінетичному періоді відновлення організму щурів}

\author{
С. Л. Попель
}

\section{Прикарпатський національний університет імені Василя Стефаника, Івано-Франківськ, Україна}

Вивчено гістоультраструктурні зміни різних структурних компонентів прямого м'яза стегна статевозрілих щурів-самців у віддалені терміни гіпокінезії та за подальшого застосування фізичного навантаження середньої аеробної потужності. Світлооптичним, електронномікроскопічним (для виявлення структурних перетворень м'язових компонентів) і гістохімічним (для визначення м'язових волокон різного фенотипу за активністю сукцинатдегідрогенази за Нахласом) методами у 55 статевозрілих щурів вивчали структурний слід адаптації м'язових волокон за тривалої (240 діб) гіпокінезії та 15-30-разового фізичного навантаження середньої аеробної потужності у післягіпокінетичному періоді. За тривалої гіпокінезії у першу чергу спостерігали зміни внутрішньом'язової ангіоархітектоніки 3 подальшим морфометричним перекабліруванням гемокапілярів. Ці дані тісно корелюють із прогресуючими змінами субклітинних компонентів, відповідальних за енергетичний і пластичний баланс м'язових волокон. Швидкі окисно-гліколітичні м'язові волокна та їх периферичний нервовий апарат найчутливіші до тривалої гіпокінезії. У результаті фізичного навантаження середньої аеробної потужності інтенсифікується фізіологічна регенерація, що істотно скорочує терміни відновлення структурно-функціональних властивостей скелетних м'язів за гіпокінетичної хвороби. Таким чином, за тривалої гіпокінезії первинні зміни торкаються джерел кровопостачання скелетних м'язів, із вторинним розвитком зворотних процесів у м’язових волокнах і периферичному нервовому апараті з певними морфометричними ознаками.

Ключові слова: гіпокінезія; м’язові волокна; гемокапіляри; фізичне навантаження

Вступ

Одна з причин зростання цілої низки захворювань серцевосудинної та ендокринної системи - зниження рівня рухової ак- тивності. Це послужило основою для виділення такої нозологічної одиниці як гіпокінетична хвороба (Guttridge, 2012; Afonin, 2016). На сучасному етапі розвитку морфологічної науки не з'ясовані окремі аспекти впливу тривалої гіпокінезії на органи опорно-рухо- 
вого апарату, тому подальше дослідження цього питання залишається актуальною науковою проблемою. Зміни в організмі людини викликають підвищену увагу не тільки лікарів та фізіологів, а й спеціалістів у галузі фізичної культури та спорту, оскільки вирішення цієї проблеми може створити основу для розробки оптимальних рухових режимів у людей різного віку та статі, враховуючи специфіку їх професії (Kуba, 2016).

Багато авторів (Voigt, 2010; Ishikura et al., 2012; Zorbas et al., 2012), відмічають успіхи морфологічних досліджень із застосуванням електрофізіологічних методів та мікродіалізу, що дало змогу вивчити характер порушень у коркових ядрах рухових аналізаторів в умовах експериментальної моделі гіпокінезії та, більш широко, подати характеристику змін за метаболічного синдрому, де пониження рівня рухової активності відіграє особливу роль.

Незважаючи на ці успіхи, у сучасній нейроморфології питанням впливу гіпокінезії на складові компоненти скелетних м'язів не приділяється належна увага (Aguado et al., 2017). Залишається не вирішеною проблема чутливості м'язових волокон різного фенотипу до гіпокінезії, а також реакція гемомікроциркуляторного русла за таких умов (Schiaffino et al., 2016).

Деструктивні процеси в скелетних м'язах достатньо часто виникають на грунті попередньої тривалої гіпокінезії (Amtage et al., 2013; Afonin, 2016), яка часто зумовлена умовами життя, особливостями професії, віком, різноманітними захворюваннями, іммобілізацією різних частин тіла людини після травм опорнорухового апарату (Leermakers and Gosker, 2016). У дослідженнях окремих авторів (Zorbas et al., 2012; Tylicki et al., 2015) показана зміна не тільки функції, а й метаболізму в скелетних м'язах за гіпокінезії-гіподинамії, однак дані про їх структурну перебудову за таких умов залишаються фрагментарними та потребують подалышого вивчення (Nevo et al., 2010; Sakuma et al., 2014). Пошук чинників, які прискорюють відновлення функції скелетних м'язів після тривалої гіпокінезії, дозволив виявити позитивний вплив дозованого фізичного навантаження на їх фізіологічну регенерацію (Schiaffino et al., 2013). Враховуючи його потужний стимулювальний вплив на різноманітні органи та тканини людського організму (Shpakov et al., 2010), ми поставили за мету дослідження виявити особливості структурної перебудови м'язових волокон за гіпокінезії та дозованого фізичного навантаження у постгіпокінетичному відновному періоді.

\section{Матеріал і методи досліджень}

Експеримент проведений на 55 дорослих щурах-самцях лінії Вістар. У першій серії експерименту обмеження рухової активності (240 діб) проводили у спеціальних клітках-пеналах (4). Досліджували структуру прямого м'яза стегна. Забір матеріалу під час експериментальної тривалої гіпокінезії проводили через 90, 180 (по 5 тварин у кожному терміні дослідження) і 240 діб (15 тварин). Контрольна група складалася 315 інтактних тварин, яких утримували у стандартних умовах віварію, та по 5 тварин виводили з експерименту у вказані вище терміни для дотримання чистоти експерименту, щоб усунути вплив вікових змін на результати мрофометричного аналізу в кожному терміні дослідження.

У другій серії експерименту у 10 тварин, які заздалегідь витримали умови тривалої гіпокінезії протягом 240 діб, фізичне навантаження середньої аеробної потужності моделювали в тредмілі (щоденні тренування упродовж 15 хвилин за швидкості бігу 20 м/Хв). Після чого їх виводили з експерименту через 15 і 30 діб (по 5 тварин у кожен термін). Контроль проводили з результатами, одержаними у 5 тварин попередньої групи, тобто після 240 діб тривалої гіпокінезії. Всі дослідження проведені згідно з «Правилами проведення робіт із використанням лабораторних тварин».

Матеріал для гістологічного дослідження обробляли гематоксиліном і еозином за загальноприйнятою методикою. Для дослідження м'язових тканин за Більшовським - Грос шматочки об'ємом 0,5 см³ фіксували в рідині, яка складається з рівних частин 96,0\% спирту, нейтрального формаліну та насиченого розчину миш'яковистої кислоти протягом 1 години. Потім їх без промивання переносили в $12 \%$ нейтральний формалін на 10 діб. Після цього шматочки споліскували у дистильованій воді та різали на заморожувальному мікротомі (МКП-4, ПО “ХЗМТ", Харків, Україна). Зрізи товщиною 25 мкм переносили в $20 \%$ розчин азотнокислого срібла, де час їх перебування встановлювали дослідним шляхом, і продовжували процедуру імпрегнації на окремих зрізах. Потім зрізи швидко проводили через 4-5 ємностей, наповнених 20\% формаліном, приготованим на водопровідній воді, поміщали у розчин аміачного срібла. Невеликий об'єм 20\% розчину азотнокислого срібла титрували на годинниковому склі краплями $25 \%$ розчину аміаку, поки не зникне осад. У цьому розчині зрізи імпрегнували під контролем мікроскопа. Після закінчення імпрегнації їх поміщали на 10-15 хв в аміачну воду, а потім на декілька годин - у дистильовану воду для промивання. Одержані зрізи монтували на лабораторних скельцях і покривали полістеролом.

Для визначення м'язових волокон різного фенотипу проводили гістохімічну реакцію на активність сукцинатдегідрогенази за Нахласом (Schiaffino and Reggiani, 2012). Для електронномікроскопічного дослідження матеріал готували за загальноприйнятою методикою. Ультратонкі зрізи отримували на ультрамікротомі УМТП-6М (ВО “СЕЛМІ”, Україна), контрастували за методикою Рейнольдс і переглядали в електронному мікроскопі ПЕМ-125 К (ВО “СЕЛМІ" Україна) 3 прискорювальною напругою 75 кВ із подальшим фотографуванням за збільшення від 1200 до 20000 разів. Напівтонкі зрізи завтовшки 1 мкм фарбували 1\% спиртним розчином метиленового синього $з$ додаванням $0,4 \%$ розчину їдкого натрію.

Гістологічні препарати та напівтонкі зрізи вивчали під світловим мікроскопом МС 300 (ТХР, Австрія) та фотографували за допомогою Digital camera for microscope DCM 900 (ТХР, Австрія).

Морфометрію здійснювали в усіх тварин на 20 препаратах по кожному терміну дослідження за допомогою програмного забезпечення «Image J» (NIH, USA) в автоматичному або ручному режимі з урахуванням збільшень. Структурні зміни на певному етапі дослідження аналізували в 50 полях зору та визначали: 1) загальну кількість м'язових волокон на 1 мм² площі поперечного перерізу, 2) товщину м'язових волокон, 3) абсолютну та відносну кількість гемокапілярів, 4) діаметр їх просвіту, 5) об'ємну частку сполучної та жирової тканини, 6) кількість фібробластів і макрофагів (Bosurgi et al., 2011).

Статистичну обробку даних проводили за допомогою програмного пакета Statistica 6 (StatSoft Inc., USA). Застосовували непараметричні методи дослідження (критерій Уілкоксона, Манна Уїтні). Вибіркові параметри, наведені далі в таблиці та тексті, мають такі позначення: $x$ - вибіркове середнє, SE - стандартна помилка середнього. Статистичні відмінності вважали вірогідними за $\mathrm{P}<0,05$.

\section{Результати}

Дані про зміну морфометричних показників м'язових волокон у різні терміни тривалої гіпокінезії та після фізичного навантаження середньої аеробної потужності наведені в таблиці. Через 90 діб після початку моделювання тривалої гіпокінезії на різних ділянках прямого м'яза стегна спостерігається виражений набряк і проліферація клітинних елементів навколо судинно-нервових пучків. Порівняно з контрольною групою тварин на 50\% збільшується кількість клітин фібробластичного ряду $(\mathrm{P}<0,05)$. Саркоплазма має низьку електронно-оптичну щільність, містить підвищену кількість піноцитозних пухирців, лізосом, залишкових тілець і аутофагосом (рис. 1). Ядра у м'язових волокнах містять маргінально розташований хроматин та зміщені до середини волокна. Цистерни саркоплазматичної сітки розширені, в мітохондріях виявляються редуковані кристи, порушується правильна конфігурація Z-ліній. У м'язових волокнах через 180 діб від початку моделю- 
вання тривалої гіпокінезії міофібрили розволокнені (рис. 2). Саркоплазма вакуолізована, виявляється значна кількість мієліноподібних тілець. Матрикс мітохондрій має низьку електронно-оптичну щільність. Розмір мітохондрій збільшується, а кристи зменшуються та піддаються фрагментації, концентруються в основному в зонах деструкції міофібрил, спостерігається підвищена кількість лізосом і осміофільних включень. Через 240 діб від початку моделювання тривалої гіпокінезії на фоні зменшення явищ гідратації збілышується кількість м'язових волокон із деструктивноатрофічними та паранекротичними явищами. При цьому спостерігається збільшення кількості клітин сполучнотканинного ряду (фібробластів, макрофагів, жирових клітин), а також збільшується кількість невпорядкованих пучків колагенових волокон поблизу м'язових волокон і мікросудин.

\section{Таблиця 1}

Динаміка зміни морфометричних параметрів прямого м'яза стегна за тривалої гіпокінезії та після дозованого фізичного навантаження $(\mathrm{x} \pm \mathrm{SE}, \mathrm{n}=55)$

\begin{tabular}{|c|c|c|c|c|c|c|}
\hline \multirow[t]{2}{*}{ Показники } & \multirow[t]{2}{*}{$\begin{array}{c}\text { Контрольна } \\
\text { группа }(\mathrm{n}=15)\end{array}$} & \multicolumn{3}{|c|}{ Тривала гіпокінезія, діб } & \multicolumn{2}{|c|}{$\begin{array}{c}\text { Тривала гіпокінезія + фізичне } \\
\text { навантаження середньої аеробної } \\
\text { потужності, разів }\end{array}$} \\
\hline & & $90(n=5)$ & $180(n=5)$ & $240(n=5)$ & $15(n=5)$ & $30(n=5)$ \\
\hline $\begin{array}{l}\text { Кількість м'язових волокон } \\
\text { на } 1 \text { мм² площі поперечного перерізу }\end{array}$ & $997 \pm 36,7$ & $345 \pm 23,1^{*}$ & $141 \pm 31,2^{*}$ & $97 \pm 10,3^{*}$ & $374 \pm 14,5^{\#}$ & $466 \pm 21,4^{\#}$ \\
\hline Абсолютна кількість гемокапілярів & $82 \pm 4,5$ & $42 \pm 3,3^{*}$ & $21 \pm 2,5^{*}$ & $16 \pm 1,4^{*}$ & $45 \pm 3,2^{\#}$ & $52 \pm 4,7$ \\
\hline Відносна кількість гемокапілярів & $12,1 \pm 0,22$ & $8,2 \pm 0,46$ & $6,7 \pm 0,33 *$ & $6,1 \pm 0,25^{*}$ & $8,3 \pm 1,07^{\#}$ & $9,0 \pm 1,98$ \\
\hline Об’ємна частка сполучної тканини, \% & $8,0 \pm 0,16$ & $14,0 \pm 0,85^{*}$ & $18,0 \pm 1,11^{*}$ & $25,0 \pm 1,95^{*}$ & $19,0 \pm 0,85$ & $8,0 \pm 0,23^{\#}$ \\
\hline Кількість фібробластів & $5,0 \pm 0,11$ & $10,0 \pm 0,55^{*}$ & $17,0 \pm 0,29 *$ & $26,0 \pm 3,12 *$ & $12,0 \pm 1,33^{\#}$ & $12,0 \pm 0,81$ \\
\hline Кількість макрофагів & $2,0 \pm 0,01$ & $5,0 \pm 0,34 *$ & $6,0 \pm 1,03 *$ & $5,0 \pm 1,84 *$ & $15,0 \pm 1,94^{\#}$ & $7,0 \pm 0,63^{\#}$ \\
\hline Об’ємна частка жирової тканини, \% & $4,0 \pm 0,09$ & $15,0 \pm 0,62 *$ & $19,0 \pm 1,88^{*}$ & $24,0 \pm 1,71 *$ & $12,0 \pm 0,32^{\#}$ & $4,0 \pm 0,15^{\#}$ \\
\hline
\end{tabular}

Примітки: * - $>$ < 0,05 порівняно з контрольною групою; \# - $\mathrm{P}<0,05$ порівняно $з$ показниками попередньої групи спостереження.

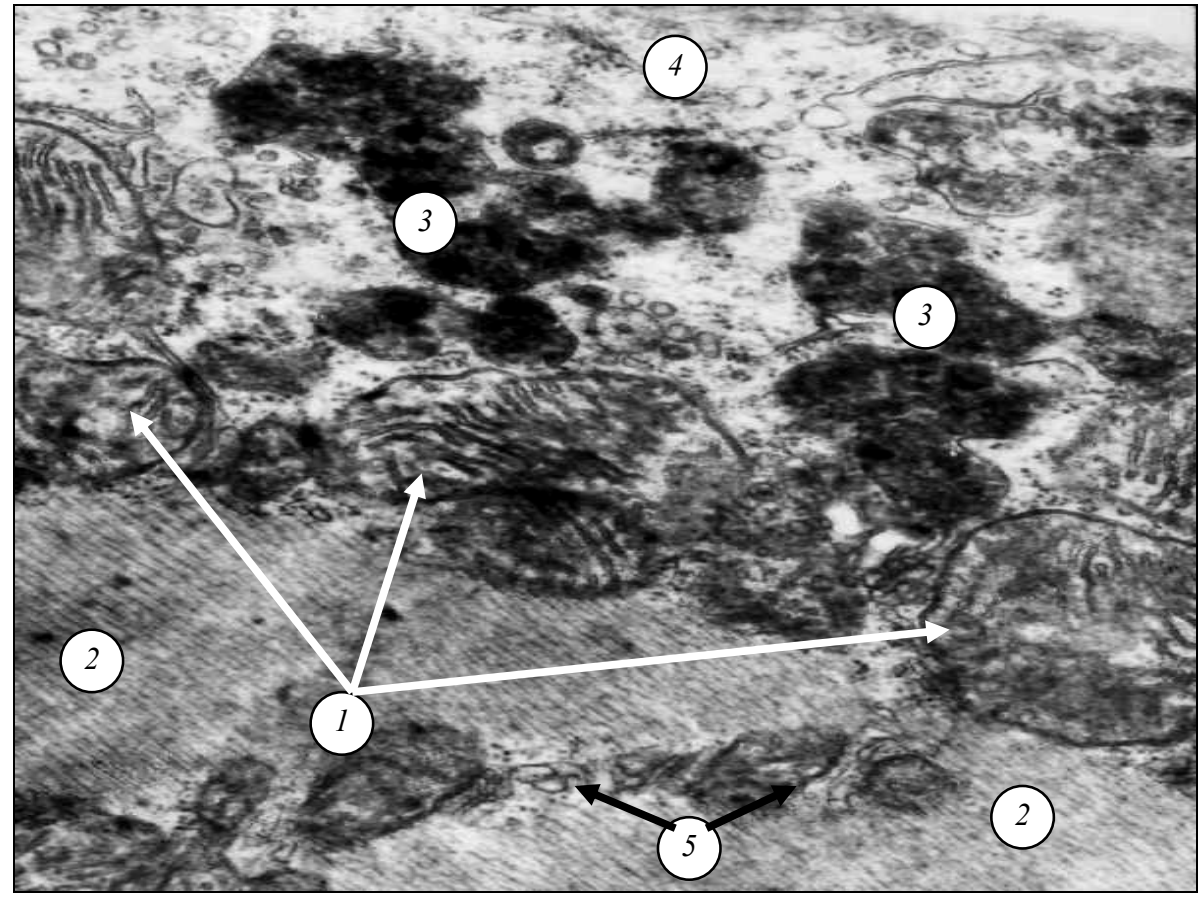

Рис. 1. Концентрація аутофагосом і залишкових тілець у ділянці локальної деструкції м’язового волокна через 90 діб після початку моделювання гіпокінезії: 1 - мітохондрія, 2 - міофібрили, 3 - залишкові тільця, 4 - саркоплазма, 5 - цистерни саркоплазматичної сітки; збільшення ${ }^{x} 12000$

М'язові волокна потоншуються, на окремих ділянках не мають поперечної смугастості, іноді утворюють локальні потовщення в цей період експерименту. Деструктивні зміни за даними електронномікроскопічного дослідження мають дифузний характер: діаметр м'язових волокон зменшується, в окремих із них спостерігаються зони лізису, поряд 3 якими збільшується кількість вторинних лізосом, залишкових тілець і аутофагосом. Контури ядер у м'язових волокнах змінюються, нуклеоплазма має низьку електронно-оптичну щільність та містить маргінований хроматин. Мітохондрії 3 матриксом низької електронно-оптичної щільності, фрагментованими та значно редукованими кристами. Іноді спостерігається руйнування зовнішньої мембрани, що викликає зменшення кількості швидких гліколітичних волокон, пониження активності сукцинатдегідрогенази у швидких окисно-гліколітичних волокнах і появу окремих деферментованих волокон (рис. 3).
Фізичне навантаження середньої аеробної потужності після тривалої гіпокінезії створює виражений та швидкий відновний ефект. Після 15-разового фізичного навантаження значно знижується кількість ділянок деструкції м'язових волокон. Паранекротичні ділянки практично не зустрічаються, спостерігаються тільки витончені, спіралеподібно скручені м'язові волокна без поперечної смугастості. Порівняно з результатами попередньої серії дослідження зменшується також набряк в ендомізіі. При цьому (табл.) утричі збільшується кількість макрофагів, удвічі зменшується кількість фібробластів, у 2,2 раза - жирових включень $(\mathrm{P}<0,05)$. Вищезгадані процеси відбуваються на обмежених ділянках поперечного перерізу м'язової тканини, не мають тенденції генералізації та ліквідовуються у перші 15 діб після фізичного навантаження середньої аеробної потужності. Звертає на себе увагу збільшення абсолютного числа гемокапілярів, які виявляються на площі 


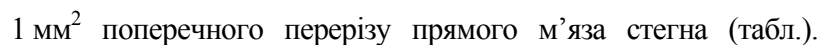
Це зумовлює збільшення площі взаємного перекриття зон кровопостачання сусідніх гемокапілярів. Збільшення кратності дії фізичного навантаження до 30 разів спричиняє появу в саркоплазмі значної кількості глікогену, канали саркоплазма- тичної сітки розширяються. При цьому значно зменшується відносна частка жирової тканини в ендомізії (табл.).

В ендотеліоцитах внутрішньом'язових гемокапілярів згладжується мікрорельєф люмінальної поверхні, підвищується кількість та діаметр мікропіноцитозних пухирців.

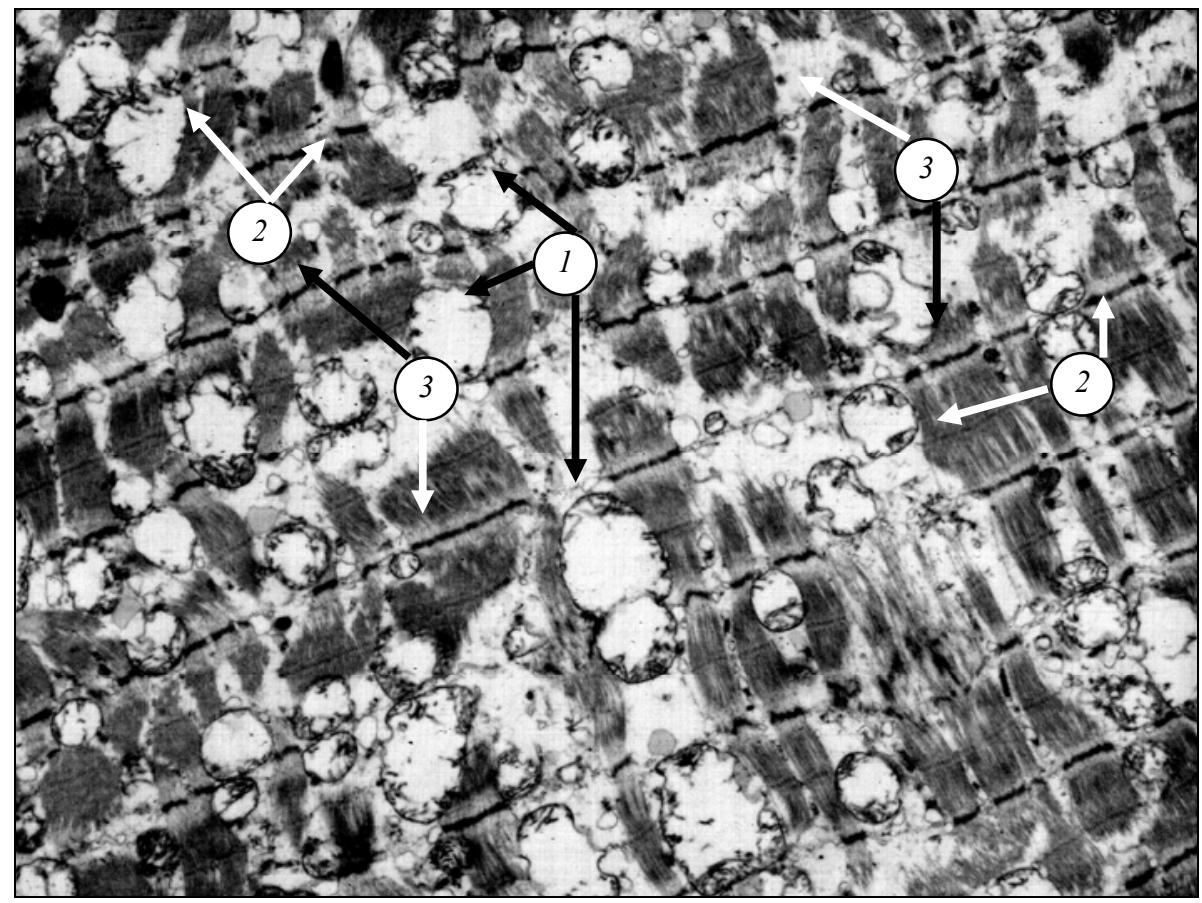

Рис. 2. Ультраструктурна організація м’язового волокна через 180 діб після початку моделювання тривалої гіпокінезії: спостерігається набряк більшості мітохондрій із вкороченням і фрагментацією крист; 1 - мітохондрія, 2 - міофібрили, 3 - Z-лінія; збільшення ${ }^{\mathrm{x}} 6000$

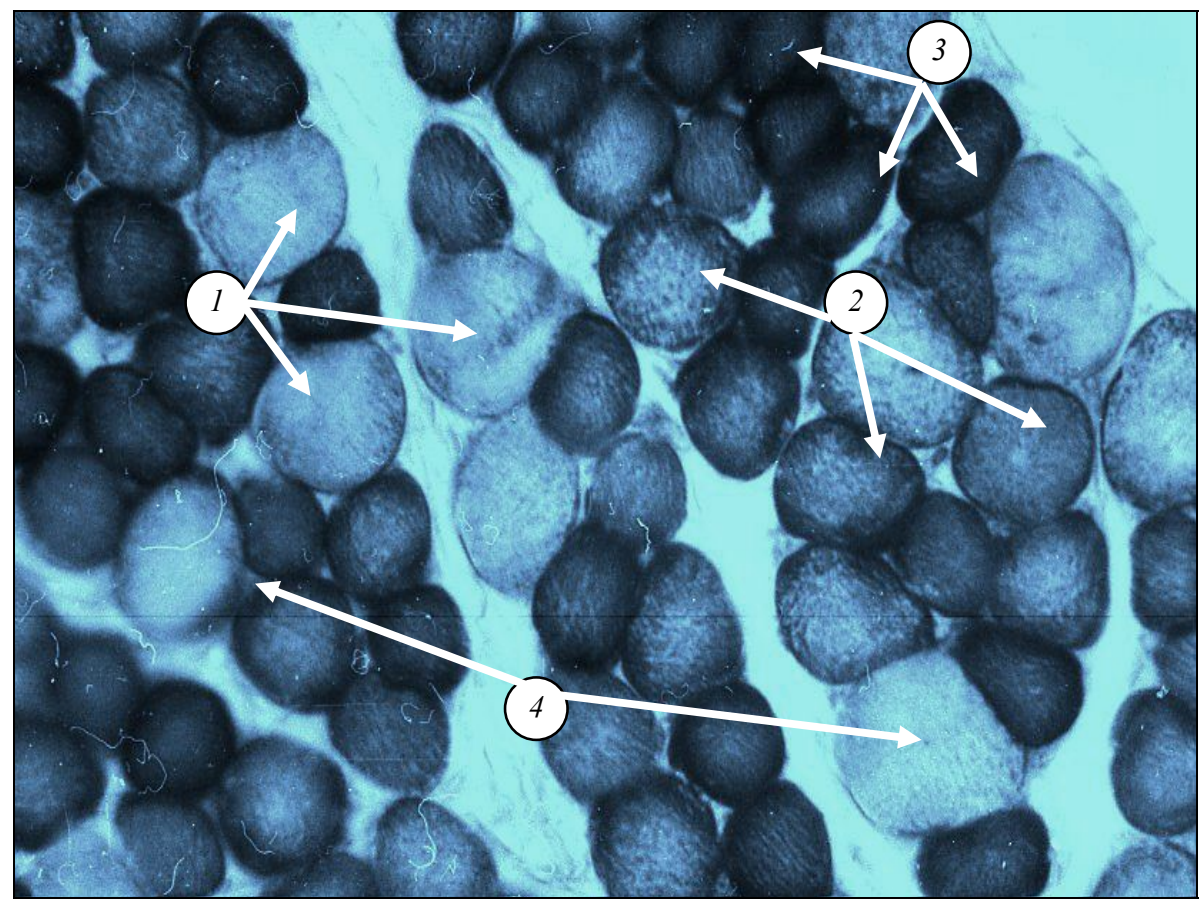

Рис. 3. Активність ферментативної реакції на сукцинатдегідрогеназу у м'язових волокнах різних типів через 240 діб після початку моделювання тривалої гіпокінезії на поперечному зрізі прямого м'яза стегна: 1 - швидкі гліколітичні м'язові волокна,

2 - швидкі окисно-гліколітичні м'язові волокна, 3 - повільні окисні м'язові волокна, 4 - деферментація м'язових волокон; метод виявлення активності сукцинатдегідрогенази за Нахласом; збільшення х 600

\section{Обговорення}

Вивчення скелетних м'язів при багатьох фізіологічних і патологічних процесах підтвердило думку окремих дослідників (Shpakov et al., 2010; Suetta and Kjaer, 2010; Sumi, 2014) про досить високу чутливість їх складових до умов тривалої гіпокінезії. Виявлені зміни м'язових волокон уже через 90 діб після початку моделювання тривалої гіпокінезії свідчать про їх неспецифічність, оскільки вони часто зустрічаються за деяких міопатій (Rayavarapu et al., 2013; Sakuma, 2014), а також як реакція адаптації м'язів до метаболізму в умовах порушення мікроциркуляції крові (Schiaffino et al., 2013). 
За гіпокінезії відбувається звуження просвіту гемокапілярів, затримання продуктів обміну, блокується транспорт кисню, що викликає тканинну гіпоксію (Liu et al., 2012; Sfyri et al., 2015). Вона, у свою чергу, спричиняе локальну гідратацію клітинних компонентів і позаклітинного простору у скелетних м'язах (Guttridge, 2012).

Спостерігається пониження електронно-оптичної щільності більшості мітохондрій з укороченням і фрагментацією крист, що викликає зменшення активної робочої поверхні мітохондрій, внаслідок чого створюються передумови для виникнення дефіциту макроергічних сполук, і свідчить про глибокі зміни внутрішньоклітинних метаболічних процесів (Melkonvan, 2005; Liu et al., 2012). Цистерни саркоплазматичної сітки звужуються, що може сприяти гальмуванню транспортних процесів на іiї мембранах. Такі зміни відображаються на гістохімічній перебудові м'язових волокон, яка проявляється декомпозицією скелетних м'язів (Guttridge, 2012; Pichavant and Pavlath, 2014). Кінцеві відділи Т-трубочок редукуються, збільшується кількість залишкових тілець, аутофагосом, мієлінових фігур - наслідок структурної трансформації м'язових волокон за тривалої гіпокінезіï (Demontis et al., 2013; Merlini et al., 2014; Schiaffino et al., 2016).

Зменшення абсолютної та відносної кількості гемокапілярів за тривалої гіпокінезії викликає ішемію, внаслідок якої відбувається збільшення кількості жирових клітин та фібробластів, що служить причиною збільшення об'ємної частки сполучної тканини в цілому (Bosurgi et al., 2011; Kassem, 2014; Forcales, 2015).

Сукупність морфологічних змін у прямому м'язі стегна за тривалої гіпокінезії можна кваліфікувати як паранекротичний процес (Ciciliot and Schiaffino, 2010; Kyba, 2016). Оскільки будь-який подразник за певної сумарної інтенсивності або дози може викликати загибель клітин, вплив тривалої гіпокінезії слід розглядати як певний етап на шляху до деструкції м'язових волокон у відповідь на функціональну депривацію. Саме відсутність функції вказується як найчастіша причина морфофункціональних порушень соматичних клітин у різних тканинах організму тварин і людини (Pichavant and Pavlath, 2014; Tylicki et al., 2015; Schiaffino et al., 2016). Із цього погляду паранекроз може швидко перейти в некроз, морфологічні ознаки якого ми спостерігали в окремих м'язових волокнах у віддалені терміни тривалої гіпокінезії. Проте паранекроз відрізняється від істинного некрозу звротністю деструктивних процесів. Тому в окремих зарубіжних публікаціях цей термін замінюється поняттям «зворотне пошкодження». Відмінності перебігу цього процесу залежно від природи або дози діючого чинника на різні тканини вивчали багато авторів (Amtage et al., 2013; Polkovenko, 2014; Aguado et al., 2017). Вони зазначають, що зворотні пошкодження характеризуються своєю неспецифічністю, оскільки дія різних чинників викликає однотипний комплекс структурних змін. Разом із такою неспецифічністю спостерігається і ціла низка специфічних ознак. Така часткова специфічність виявляється при багатьох патологічних процесах (Buričová et al., 2011; Leermakers and Gosker, 2016). Слід зазначити, що зворотні пошкодження за тривалої гіпокінезії виникають на фоні редукції внутрішньом'язової мікроциркуляції крові (Nemeth et al., 2003; Novoselova et al., 2008).

Доведено факт швидкого відновлення та активації мікроциркуляції крові під час фізичного навантаження (Gajdosik, 2001; Ertunc et al., 2010; DiFranco et al., 2015). Проте залишається поза увагою дослідників питання про енергетичну спрямованість такого навантаження. У науковій літературі, особливо в галузі фізичної культури та спорту, існують іноді діаметрально протилежні погляди на застосування фізичного навантаження анаеробного або аеробного характеру в різних реабілітаційних схемах після травм, які супроводжуються вимушеним тривалим ліжковим режимом (Deogenov et al., 2009).

Скелетні м'язи становлять окремий інтерес, оскільки від швидкості їх морфофункціонального відновлення часто залежить подальша перспектива спортсмена. Тому морфологічні дослідження закономірностей їх регенерації під час фізичного навантаження середньої аеробної потужності необхідні для розроблення сучасних реабілітаційних методик. Виявлена нами позитивна динаміка у відновленні структури мікросудин вже після 15-разового фізичного навантаження середньої аеробної потужності відображає тісний характер взаємної перебудови гемомікроциркуляторного русла та складових компонентів скелетних м'язів (Novoselova et al., 2008; Schiaffino and Patridge, 2008; Schiaffino and Reggiani, 2012).

Будучи негентропійним чинником, фізичне навантаження середньої аеробної потужності зумовлює швидкий зворотний перебіг деструктивних процесів після тривалої гіпокінезії (Abzalov and Sitdikova, 1985; Canu et al., 2003). Про це свідчить відновлення не тільки більшості внутрішньоклітинних органел, а й кількості гемокапілярів, зменшення об'ємної частки сполучної тканини та фібробластів. При цьому спостерігається збільшення кількості макрофагів, які прискорюють утилізацію продуктів розпаду м'язових волокон (Bosurgi et al., 2011).

Таким чином, прискорене відновлення скелетної м'язової тканини за впливу фізичного навантаження свідчить про стимуляцію метаболічних процесів, які реалізуються за допомогою збільшення кількості гемокапілярів та мітохондрій, що забезпечує м'язове волокно енергією та пластичним матеріалом. Потужний ефект регенерації, який спостерігається під час фізичного навантаження середньої аеробної потужності, можна пояснити впливом активного механічного розтягнення дистрофічно змінених м'язових волокон, на фоні активованого кровообігу у м'язах під час бігу тварин у тредмілі, що підтримує високий рівень метаболічних процесів.

\section{Висновки}

Тривала гіпокінезія - причина паранекротичних змін, які проявляються порушенням структури ядра, мітохондрій, саркоплазматичної сітки у більшості м'язових волокон, що на фоні деструктивних змін гемокапілярів стає причиною зниження метаболічного забезпечення внутрішньоклітинних компонентів скелетного м'яза, яке відображається у зміні ферментативної активності на сукцинатдегідрогеназу у м'язових волокнах різних фенотипів.

Дозоване фізичне навантаження аеробного характеру посилює репаративну регенерацію скелетних м'язів після тривалої гіпокінезії, що підтверджується кількісно-якісними даними морфометричного дослідження складових елементів м'язових волокон.

\section{References}

Abzalov, R. A., \& Sitdikova, R. R. (1985). Effect of hypokinesia and muscular training on stroke, control patterns in rats. Bulletin of Experimental Biology and Medicine, 100(2), 1043-1045.

Afonin, B. V. (2016). Dynamics of the glycemic profile in women in longterm antiorthostatic hypokinesia. Human Physiology, 42(4), 425-431.

Aguado, E., Mabilleau, G., Goyenvalle, E., \& Chappard, D. (2017). Hypodynamia alters bone quality and trabecular microarchitecture. Calcified Tissue International, 100(4), 332-340.

Amtage, F., Feuerstein, T. J., Meier, S., Prokop, T., Piroth, T., \& Pinsker, M. O. (2013). Hypokinesia upon pallidal deep brain stimulation of dystonia: Support of a GABAergic mechanism. Frontiers in Neurology, 4, 1-5.

Bosurgi, L., Manfredi, A., \& Rovere-Querini, P. (2011). Macrophages in injured skeletal muscle: A perpetuum mobile causing and limiting fibrosis, prompting or restricting resolution and regeneration. Frontiers in Immunology, 2(11), 234-240.

Buričová, L., Škrobánek, P., \& Baranovská, M. (2011). Effect of hypodynamia on structure of vestibular apparatus in Japanese quail chicks: Light microscopy. Acta Veterinaria Brno, 80(1), 125-127.

Canu, M.-H., Langlet, C., Dupont, E., \& Falempin, M. (2003). Effects of hypodynamia-hypokinesia on somatosensory evoked potentials in the rat. Brain Research, 978, 162-168.

Ciciliot, S., \& Schiaffino, S. (2010). Regeneration of mammalian skeletal muscle. Basic mechanisms and clinical implications. Current Pharmaceutical Design, 16(8), 906-914. 
Demontis, F., Piccirillo, R., Goldberg, A. L., \& Perrimon, N. (2013) Mechanisms of skeletal muscle aging: insights from Drosophila and mammalian models. Disease Models and Mechanisms, 6(6), 1339-1352.

Deogenov, V. A., Zorbas, Y. G., Kakuris, K. K., \& Federenko, Y. F. (2009) The impact of physical exercise on calcium balance in healthy subjects during prolonged hypokinesia. Nutrition, 25(10), 1029-1034.

DiFranco, M., Yu, C., Quiñonez, M., \& Vergara, J. L. (2015). In ward rectifier potassium currents in mammalian skeletal muscle fibres. Journal of Physiology, 593(5), 1213-1238.

Ertunc, M., Atalay, A., Yildirim, M., \& Onur, R. (2010). Exercise and suspension hypokinesia-induced alterations in mechanical properties of rat fast and slow-twitch skeletal muscles. Acta Physiologica Hungarica, 97(3), 316-325.

Forcales, S.-V. (2015). Potential of adipose-derived stem cells in muscular regenerative therapies. Frontiers in Aging Neuroscience, 7, 1-12.

Gajdosik, R. L. (2001). Passive extensibility of skeletal muscle: Review of the literature with clinic alimplications. Clinical Biomechanics, 16(2), 87-101.

Ishikura, F., Takano, Y., \& Ueyama, T. (2012). Amlodipine has a preventive effect on temporal left ventricular hypokinesia after emotional stress compared with an angiotensin II receptor blocker. Journal of Medical Ultrasonics, 40(1), 3-7.

Kassem, M. (2014). Skeletal (stromal) stem cells - basic biology and clinical use in tissue regeneration. Hamdan Medical Journal, 7(4), Suppl. 1.

Kyba, M. (ed.), 2016. Skeletal muscle regeneration in the mouse. SpringerVerlag, New York.

Leermakers, P. A., \& Gosker, H. R. (2016). Skeletal muscle mitophagy in chronic disease. Current Opinion in Clinical Nutrition and Metabolic Carevolume, 19(6), 427-433.

Liu, G., MacGabhann, F., \& Popel, A. S. (2012). Effects of fiber type and size on the heterogeneity of oxygen distribution in exercising skeletal muscle. PLoS ONE, 7(9), 443-475.

Melkonvan, K. (2005). Relationship between cerebrovascular diseases and hypokinesia. Atherosclerosis Supplements, 6(1), 149.

Merlini, L., Vagheggini, A., \& Cocchi, D. (2014). Sarcopenia and sarcopenic obesity in patients with muscular dystrophy. Frontiers in Aging Neuroscience, 6, 1-6.

Nemeth, N., Lesznyak, T., \& Brath, G. (2003). Changes in microcirculation after ischemic process in rat skeletal muscle. Microsurgery, 23(5), 419-423.

Nevo, Y., Halevy, O., Genin, O., Moshe, I., Turgeman, T., Harel, M., Biton, E., Reif, S., \& Pines, M. (2010). Fibrosis inhibition and muscle histopathology improvement in laminin-alpha2-deficient mice. Muscle Nerve, 42, 218-229.

Novoselova, A. M., Custaud, M. A., Tsvirkun, D. V., Larina, I. M., \& Kulchitsky, V. A. (2008). Metabolism in rats during antiorthostatic hypokinesia. Bulletin of Experimental Biology and Medicine, 146(1), 38-40.
Pichavant, C., \& Pavlath, G. K. (2014).Incidence and severity of myofiber branching with regeneration and aging. Skeletal Muscle, 4(1), 9.

Polkovenko, O. V. (2014). Histostructure changes in proxymal and distal metaphyses of white rats' femoral bones under experimental hypokinesia. ScienceRise, 3(1), 31-34.

Rayavarapu, S., Coley, W., Kinder, T. B., \& Nagaraju, K. (2013). Idiopathic inflammatory myopathies: Pathogenic mechanisms of muscle weakness. Skeletal Muscle, 3(1), 13.

Sakuma, K., Aoi, W., \& Yamaguchi, A. (2014). The intriguing regulators of muscle mass in sarcopenia and muscular dystrophy. Frontiers in Aging Neuroscience, 6, 1-7.

Schiaffino, S., \& Patridge, T. (eds.), 2008. Skeletal muscle repair and regeneration. Springer, New-York.

Schiaffino, S., \& Reggiani, C. (2012). Skeletal muscle fiber types. Muscle Fundamental Biology and Mechanisms of Disease, 2, 855-867.

Schiaffino, S., Dyar, K. A., Ciciliot, S., Blaauw, B., \& Sandri, M. (2013). Mechanisms regulating skeletal muscle growth and atrophy. FEBS Journal, 280(17), 4294-4314.

Schiaffino, S., Pereira, M. G., Ciciliot, S., \& Rovere-Querini, P. (2016) Regulatory T-cells and skeletal muscle regeneration. FEBS Journal, 284(4), 517-524.

Sfyri, P., Narkar, V., \& Matsakas, A. (2015). Regulation of skeletal muscle metabolic and angiogenic properties by nuclear hormone receptors: Implications for skeletal muscle regeneration. Neuromuscular Disorders, 25, 185.

Shpakov, A. V., Artamonov, A. A., Voronov, A. V., \& Melnik, K. A. (2010). The effect of immersion hypokinesia on the kinematic and electromyographic parameters of human locomotion. Human Physiology, 36(7), 828-832.

Stogov, M. V. (2009). Creatine metabolism in skeletal muscles during hypokinesia. Bulletin of Experimental Biology and Medicine, 148(1), 26-28.

Suetta, C., \& Kjaer, M. (2010).What are the mechanisms behind disuse and age-related skeletal muscle atrophy? Scandinavian Journal of Medicine and Science in Sports, 20(2), 167-168.

Sumi, S. M. (2014). Muscular system disorders. School of Medicine, University of Washington, Seattle.

Tylicki, A., Strumilo, J., \& Kondracikowska, J. (2015). Comparative properties of pyruvate kinase and lactate dehydrogenase from muscles of pigeons with motor activity and hypodynamia. Journal of Evolutionary Biochemistry and Physiology, 51(1), 69-71.

Voigt, T. (2010). Early effects of carbachol on the morphology of motor endplates of mammalian skeletal muscle fibers. Marin Muscle and Nerve, 41(3), 399-405

Zorbas, Y. G., Deogenov, V. A., Fedorov, M. A., \& Federenko, Y. F. (2012). Magnesium supplementation effect on magnesium absorption during prolonged hypokinesia in rats. Trace Elements and Electrolytes, 29(1), 7-14. 